XII.

\title{
NOTES ON THE AQUATIC PLANTS OF GEORGIAN BAY.
}

\author{
By A. B. KıJGH, M.A., Queen's University, Kingston.
}

During the latter part of August and the first three weeks of September, 1912, I was engaged in a study of the Hydrophytes of Georgian Bay in connection with the Biological Station at Go Home Bay, Muskoka. In company with Mr. A. D. Robertson, M.A., I made a trip round the Bay, collecting along the shore at numerous points. A full report upon the Algæ collected on this trip is given in my paper in "Rhodora.," Vol. 15, No. 173 (May, 1913), in which a new species of Rivularia is described, and twelve species of Algæ new to Canada are recorded.

The following are the records of the Pteridophytic and Spermatophytic Hydrophytes observed on the trip referred to.

\section{PTERIDOPHYTA.}

Isoeles macrospora. Dur. Growing on muddy bottom in eight feet of water near the mouth of the Shawanaga River Aug. 26.

Isoetes echinospora braunii Engelm. Growing submerged near shore in the Shawanaga River Aug. 27. Submerged in a foot of water at Killarney Sept. 4. Submerged, in Collins' Inlet Sept. 3.

\section{SPERMATOPHYTA.}

\section{MONOCOTYLEDONEA.}

Sparganium simplex, Huds. In lake off Shawanaga River, Aug. 27.

Potamogeton natans, L. Severn River, Aug. 21. At mouth of Shawanaga River, Aug. 27.

Potamogeton heterophyllus, Schreb. Waubaushene, Aug. 27. In lake off Shawanaga River, Aug. 27.

Potamogeton epihydrus cayugensis, Benn. In the French River at foot of the last rapids, Sept. 1.

Potamogeton lucens, L. At mouth of Shawanaga River, Aug. 26.

Potamogeton perfoliatus, L. Severn River and covering large areas of water in Georgian Bay at mouth of Severn River, Aug. 21. Near mouth of Shawanaga River, Aug. 26. French River, Sept 1. Killarney, Sept 4.

Potamogeton zosterifolius, Schw. Near the mouth of the Shawanaga River, Aug. 26. Waubaushene, Aug. 21.

Potamogeton pusillus tenuissimum, Mertens and Koch. In a very small almost cut-off inlet in one of the Bustard Islands off French River. Aug. 30. 
Potamogeton dimorphus, Raf. In lake off Shawanaga River, Aug. 27. In little almost cut-off inlet in one of the Bustard Islands off French River, Aug. 30. In pool at the foot of the last rapids on the French River, Sept. 1.

Potamogeton pectinatus, L. Matchedash Marsh, Waubaushene, Aug. 24. Killarney, Sept. 4.

Najas flexilis, Rostk \& Schmidt. Waubaushene, Aug. 21. In lake off Shawanaga River, Aug. 27. In the Shawanaga River, Aug. 26. In pool at foot of the last rapids on the French River, Sept. 1.

Elodea cxnadensis, Michx. Waubaushene, Aug. 21. In pool at foot of last rapids on the French River, Sept. 1.

Vallisneria spiralis L. Waubaushene, Aug. 21. In pool at foot of last rapids on the French River, Sept. 1.

DICOTYLEDONEAS.

Ceratophyllum demersum, L. Waubaushene, near Canary Island, Aug. 21.

Nymphaea advena, Ait. Severn River Aug. 21, In the Shawanaga River, Aug. 26. In lake off the Shawanaga River, Aug. 27. In pool at foot of last rapids on the French River, Sept. 1. In Collin's Inlet, Sept. 3.

Castalia odorata, Woodville \& Wood. In lake off the Shawanaga River, Aug. 27. In pool at foot of last rapids on the French River, Sept. 1. In Collin's Inlet, Sept. 3.

Brasenia schreberi, Gmel. In lake off the Shawanaga River, Aug. 27.

Callitriche autumnalis, L. In little almost cut-off inlet in one of the Bustard Islands off French River, Aug. 30.

Hypericum boreale, Bicknell. Submerged form; in the Shawanaga River, Aug. 27. Myriophyllum spicatum, L. In the Severn River, Aug. 21. At the mouth of the Shawanaga River, Aug. 26. In little almost cut-off inlet in one of the Bustard Islands off French River, Aug. 30. In pool at the foot of the last rapids on the French River, Sept. 1.

Myriophyllum heterophyllum, Michx. In pool at foot of the last rapids on the French River, Sept. 1.

Nymphoides lacunosum, Fernald. In lake off the Shawanaga River, Aug. 27. 